\title{
Cost benefit analysis of cassava production in Sherpur district of Bangladesh
}

\author{
N. Afreen ${ }^{1}$ and M. S. Haque ${ }^{2^{\star}}$ \\ ${ }^{1}$ Bangladesh Rice Research Institute, Bangladesh and ${ }^{2}$ Department of Agricultural Finance, Bangladesh Agricultural \\ University, Mymensingh-2202, Bangladesh. *E-mail-mshbau@yahoo.com
}

\begin{abstract}
The present study was designed to analyze the cost, benefit and profitability of cassava production in selected areas of Sherpur district in Bangladesh. Data were collected by interviewing a representative sample of 100 practicing cassava farmers, taking each 50 sample from traditional farmers of Jhinaigati and commercial cassava farmers of Sreebardi Upazila. Analyses showed that per hectare cost incurred for cassava was BDT 41,417.22 in Jhinaigati whereas BDT 53,642.59 in Sreebardi Upazila. The average return for cassava was BDT 103,297.58 and BDT $159,527.70$ in Jhinaigati and Sreebardi Upazila respectively. Average gross margin for cassava was BDT 61,880.36 and BDT 105,885.10 in Jhinaigati and Sreebardi Upazila respectively. Results of the financial analysis indicate that investment in cassava is profitable since BCR was for cassava were 2.49 and 2.99 in Jhinaigati and Sreebardi Upazila respectively. The technical efficiency analysis reveals that technical inefficiency effects presence in cassava production in the study areas. The estimates for the stochastic frontier cost functions parameters imply that as some cost factors, e.g., cost of labor, power tiller, seedlings, fertilizer, and interest on operating capital increased, total production cost increased. Hence, these variables are important determinants of cassava production in the study area. In a nutshell, though the technical inefficiency exists in the cassava production, it is profitable and, therefore, be replicated in other areas of Bangladesh.
\end{abstract}

Keywords: Bangladesh, Cassava, Cost and Benefit, Profitability, Efficiency

\section{Introduction}

Cassava (Manihotesculenta), also called yuca or manioc, is a woody shrub of the Euphorbiaceae (spurge family) native to South America. Itis regarded as the crop of last resort for millions of marginal farmers and their domestic animals in tropical regions (Arena, 2005). Cassava is mainly produced for its edible starchy tuberous root, a major source of carbohydrates, which is actually a swollen root but its leaves also can be taken as vegetables in many parts of Africa and Asia including Bangladesh.

Although Bangladesh does not produce a remarkable amount of cassava but the volume of its use in Bangladesh for industrial and bakery purposes is not negligible. However, there is no reliable statistics of cassava production and its use in Bangladesh. Commonly, it is cultivated sporadically throughout the country. Few private farms are cultivating cassava in an area of 12-15 hectares land by employing farmers on contract basis (Shams-Ud-Din and Talukder, 2002).

In order to meet up the growing demands of cassava, Bangladesh had been started import of cassava. Since1986 total cassava imports is increased year by year. In 1986, the quantity of cassava imports was 460 tones worth of US $\$ 11,000$ which increased in 2008 as 5,796 tones valuing US $\$ 196,100$ (FAOSTAT Database 2001).

While there is a plethora of agronomic research works on production of cassava and its various uses around the world, no socio-economic study has yet been carried out in Bangladesh. Taking all these consequences in mind, study on economics of Cassava production and thereby formulating appropriate policy strategies for popularizing cassava as an alternative food for majority of Bangladeshi people cannot be overstated.

Therefore, the main purpose of the study is to obtain a comprehensive insight into the profitability of Cassava production. The specific objectives of the study are (i) to examine the socio-economic profile of the Cassava producers; (ii) to determine the profitability of cassava production in the study areas; and (iii) to estimate the technical and economic efficiency of cassava production. 


\section{Methodology of the study}

\section{Selection of the study area}

In Bangladesh cassava is produced in traditional way mainly for meeting household consumption requirement by majority of the cassava farmers and tribal people who are used to consume such crop. Recently, cassava is producing commercially, as few private commercial companies came forward to motivate the farmers and made some contractual agreement to produce cassava jointly. Therefore, care has been given for selecting the desired cassava farms based on its type of production techniques, i.e., commercial and private or traditional. In this study, two Upazilas (Sub-districts) namely, Jhinaigati and Sreebardi Upazila from Sherpur district were selected for collecting primary data. Jhinaigati Upazila is considered as traditional cassava producing area. Most of the farmers in these areas cultivate cassava in their own way. On the other hand, Sreebardi Upazila is considered as commercially cassava grown areas where it is produced under contract farming using modern farming technology. Primary data were collected from three villages namely, Bokultola, Chandapara, and Meghadol of Sreebardi Upazila and two villages namely Rangtia and Noukushi of Jhinaigati Upazila. Reasons for selecting the study areas were as follows: (i) the study areas were popular for cassava production where a major volume of cassava is grown in Bangladesh; and (ii) majority of the cassava growers, living in the study areas are indigenous, who often take it as their alternative carbohydrate source.

\section{Sampling and data collection}

Since there is no systematic record of cassava producing farmers with any agricultural development agency of Bangladesh, a list of those farmers was prepared with the help of union council members, community leaders and NGO professionals. A representative sample of each 50 farmers from Jhinaigati Upazila and Sreebardi Upazila were randomly selected from the list. It is because there is a technological variation in the cultivation procedure of cassava in both the Upazilas. Therefore, total respondents stood at 100. The relevant primary data were collected during the month of February to October 2012 by the researchers themselves through personal interviews using a pre-tested interview schedule for the period of January to December 2011.

\section{Analytical Methods}

Measurement of costs and returns: Mainly tabular and statistical analyses, e.g., percentage, mean and standard deviation were used to achieve the objectives. In order to estimate the costs and returns and profitability of cassava production in both traditional and commercial farming gross return, gross margin, cost and return per unit and Benefit Cost Ratio (BCR) were used.

Measurement of technical and economic efficiency: A Cobb Douglas logarithmic function was employed in estimating model cassava production technology in this study. It has been employed in many empirical studies, particularly, those relating to agriculture of developing countries (Brave-ureta and Pinheiro (1997), Ajibefin, et al. (2002) etc.).

The estimated Cobb-Douglas stochastic frontier production function is assumed to specify the technologies adopted by the cassava farmers in the study areas, which can be specified in the following form:

$$
\ln Y i=\beta+\beta \ln X_{1 j}+\beta_{2} \ln X_{2 i j}+\beta_{3} \ln X_{3 i j}+\beta_{4} \ln X_{4 i j}+\beta_{5} \ln X_{5 i j}+\beta_{6} \ln X_{6 i j}+V_{i j}-\mu_{j j}
$$

Where 'In' represents logarithm to base e; subscripts $i j$ denotes to the $j$-th observation of the $i$-th farmer;

$Y i=$ value of total output of both cassava and its bi-products measured in kg;

$X_{1}=$ age of the farmers

$\mathrm{X}_{2}=$ farm size (total cultivated land area under cassava production) in hectares;

$\mathrm{X}_{3}=$ labor days (in man days);

$\mathrm{X}_{4}=$ quantity of seed/seedling (cassava stem cuttings) planted (in number);

$\mathrm{X}_{5}=$ quantity of chemical fertilizers (in kgs);

$X_{6}=$ quantity of organic fertilizers (in kgs); 
$V_{i j}=$ a symmetric error component that accounts for random effects and exogenous shocks;

$\mu_{i j} \leq 0=$ a one sided error component that measures technical inefficiency.

Also, Cobb-Douglas cost frontier function for cassava farms in the study area is specified as:

$$
\ln C_{i}=\alpha_{0}+\alpha_{1} \ln P_{1 i}+\alpha_{2} \ln P_{2 i}+\alpha_{3} \ln P_{3 i}+\alpha_{4} \ln P_{4 i}+\alpha_{5} \ln P_{5 i}+V_{i}+U_{i}
$$

Where $\mathrm{C} i=$ total cost of cassava cultivation per production cycle (in BDT);

$P_{1}=$ cost of labor (in BDT);

$P_{2}=$ cost of power tiller (in BDT);

$P_{3}=$ cost of planting materials (stem cuttings) (in BDT);

$P_{4}=$ cost of organic fertilizer (in BDT);

$P_{5}=$ interest on operating capital (in BDT) and

$V_{i}$ and $U_{i}$ as earlier defined above.

The $\alpha$ s and $\beta$ s are parameters to be estimated. The maximum-likelihood estimates of the $\alpha$ s and $\beta$ s of the frontier production and cost functions given in equation (1) and (2) respectively are estimated simultaneously using the computer program FRONTIER 4.1 (Coelli and Battese, 1996).

\section{Results and Discussions}

\section{Socio-economic profile of the respondents}

The general socio-economic profile of the surveyed respondents is presented in Table 1 . The overall average age of the cassava farmers was 41.01 years with a standard deviation of 16.00 in the Jhinaigati Upazila and 39.14 years with a standard deviation of 8.88 in the Sreebardi Upazila. Almost all of the respondents (98\%) belonged to the active age group between 18 and 50 years in both the study areas. In Jhinaigati Upazila average family size was 3.94 per household whereas in Sreebardi Upazila, it was 4.67 per household. Total male female ratio in Jhinaigati was found to be $1.26: 1$ whereas it was $0.918: 1$ in Sreebardi Upazila.

Table 1. Socio-economic profile of the Cassava farmers

\begin{tabular}{|c|c|c|c|c|c|}
\hline & Particulars & Minimum & Maximum & Mean & S.D. \\
\hline \multirow{7}{*}{ 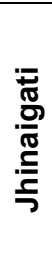 } & Age (years) & 18 & 70 & 41.01 & 16.00 \\
\hline & Family size (persons) & 2 & 7 & 3.94 & 1.52 \\
\hline & Education level (years of schooling) & 0 & 10 & 4.26 & 3.68 \\
\hline & Total landholding (hectares) & 0.80 & 2.8 & 1.76 & 0.94 \\
\hline & Annual income (BDT) & - & - & $345,711.16$ & - \\
\hline & Annual expenditure (BDT) & - & - & $331,825.99$ & - \\
\hline & Annual savings (BDT) & - & - & $13,885.17$ & - \\
\hline \multirow{7}{*}{$\begin{array}{l}\text { 흠 } \\
\frac{0}{0} \\
\frac{0}{0} \\
\text { ஸे }\end{array}$} & Age (years) & 22 & 55 & 39.14 & 8.88 \\
\hline & Family size (persons) & 3 & 7 & 4.67 & 1.20 \\
\hline & Education level (years of schooling) & 0 & 10 & 4.42 & 3.32 \\
\hline & Total landholding (hectares) & - & - & 0 & 0 \\
\hline & Annual income (BDT) & - & - & $414,191.61$ & - \\
\hline & Annual Expenditure (BDT) & - & - & $383,978.30$ & - \\
\hline & Annual savings (BDT) & - & - & 30213.31 & - \\
\hline
\end{tabular}

Note: US\$1 = BDT 79.80 as of December 30, 2012 -indicates not applicable

Source: Field Survey, 2012

The overall average year of schooling of the respondent farmers in the study area of Jhinaigati was found to be 4.26 years with a standard deviation of 3.68 whereas in Sreebardi, it was found to be 4.43 years with a standard deviation of 3.32. It appears from the table that the average farm size was 1.76 hectares per farm household with a standard deviation of 0.94 in Jhinaigati. In Sreebardi, most of the farmers utilized government owned Khas land for accommodation as well as for cultivation under forest division. So, estimation of land ownership pattern of the farmers of Sreebardi Upazila is quite complex. 
In Jhinaigati Upazila, most respondent families are tribal people and mother is the head of the family. Women have less opportunity to engage in different income generating activities rather than agriculture.So, there is a little variation found in the main professions of the respondents. Respondent families are father-headed and farmers of Sreebardi Upazila are engaged with different livelihood works. They occupied varieties of income generating economic activities as their major and minor occupations. For example, about $72 \%$ respondents were occupied in agriculture as their major occupation. Other occupations they hold as their major occupations were business $(14 \%)$ and shopkeeper $(10 \%)$.

The average annual income of the respondent family was BDT 345,711.16 in Jhinaigati Upazila and it was BDT 414,191.61 in Sreebardi Upazila. Agriculture contributed most of their total household income which was $81.19 \%$ and $90.84 \%$ in Jhinaigati and Sreebardi Upazila respectively. The average annual expenditure of the farm household was BDT 331,825.99 in Jhinaigati Upazila whereas in Sreebardi Upazila this amount was BDT $383,978.30$. About $16.19 \%$ of the total expenditure was spent on food items in Jhinaigati and $14.69 \%$ in Sreebardi Upazila for the respondent family during the study period.

\section{Costs and returns of Cassava production}

Cost items: The cost items account for cassava production are for human labor, tillage, seed, organic fertilizer, chemical fertilizer and cost on operating capital. The value of all variables and profitability of cassava were expressed in terms of Bangladeshi Taka (BDT) per hectare.

Broadly, two types of human labor were found to involve in cultivation process of cassava. These were unpaid labor that means family labor and paid labor consists of causal hired labor. The farmers had to use labors for land preparation, sowing, weeding, carrying fertilizer, spraying insecticides and harvesting of cassava. The labor was measured in man-day unit, which usually consisted of 8 hours a day. For women, man equivalent hours were estimated by converting all women hours into man equivalent hours by assigning a ratio of 1.5 women= 1 man (Yang 1965).

In Jhinaigati Upazila, the uses of human labor for Cassava production per hectare were estimated at 199 persons among which 85 male and 114 female labors respectively. It implies that women have more access to employment market in the local community. Existence of matriarchal family system in the local community helped to ensure such progress in the developing economy of Bangladesh. Detailed calculation shows that cost of land preparation, transplanting, weeding, and harvesting incurred for $10.70 \%, 18.03 \%, 29.32 \%$, and $41.93 \%$ of total labor cost respectively for Cassava production in Jhinaigati Upazila.

On the other hand, involvement of women in cassava production in Sreebardi Upazila is not prominent as like as Jhinaigati Upazila. For example, the uses of human labor in cassava production per hectare were estimated at 200 persons among which 116 male labors and 84 female labors respectively. Various costs incurred for cassava production among which cost incurred for land preparation, transplanting, weeding, harvesting $12.29 \%, 17.46 \%, 29.61 \%$, and $40.64 \%$ of total labor cost respectively.

Cassava is mainly produced in homestead garden in Jhinaigati Upazila and in hillside areas of Sreebardi Upazila. Therefore, power tiller and animal pulled ploughs were mainly used for land preparation. Few farmers were found to prepare their land with spade. For cassava production, per hectare average power tiller cost was calculated as BDT $3,078.29$ which was $7.26 \%$ of total cost in Jhinaigati Upazila.

On the contrary, since production of cassava in Sreebordi Upazila is commercial, average use of power tiller was found higher than in Jhinaigati Upazila. Consequently, per hectare average tillage cost (power tiller cost) was also found higher than cost in Jhinaigati Upazila. It was estimated as BDT 4,582.73 which was $8.23 \%$ of total cost for average number of tilling 2.57 . In Jhinaigati Upazila this cost was calculated as BDT 3,078.29.

Stem cutting of cassava is mainly used as seed for its reproduction. Farmers were found to use both home supplied and purchased stem cutting for production of cassava. Cost for such head was calculated on the basis of actual average price paid by the farmers and the home supplied seed was determined on the basis of the opportunity cost. 
In the local market, average price for cassava stem was found to be higher than in Sreebardi Upazila (BDT 2.00 per stem) compared to Jhinaighati (BDT 0.70 per stem) during the study period. Total cost of seed for cassava was estimated as BDT 1,424.69 per hectare which was $3.43 \%$ of total production cost in Jhinaigati Upazila. On the other hand, total cost of seed for cassava was calculated as BDT 4,091.38 which was $7.62 \%$ of total production cost.

Crop production requires sufficient nutrients absorptions from the soil. For a satisfactory yield level it is necessary to maintain an optimum combination of soil nutrients. Most of the time the sampled farmers used their home supplied organic fertilizers, mainly cow dung, during land preparation. The average cost of cow dung use in Cassava producing land was BDT 4,083.30 and total cow dung requirement was 136.11 mounds per hectare in Jhinaigati Upazila whereas the average cost of cow dung use was BDT4,680.65 and total requirements was 156.02 mounds per hectare in Sreebardi Upazila. The price per mound of cow dung was the same as BDT30.00 in both the study areas. The cost on this head was $8.40 \%$ of total cost of cassava production in Sreebardi Upazila which is higher than in Jhinaigati Upazila $(2.88 \%)$.

Urea, TSP and MP were the mainly used chemical fertilizers in the production of cassava in the study areas. Cost was calculated on the basis of average price paid by the farmers. Farmers, in traditionally cassava grown areas i.e., Jhinaigati Upazila only apply some extent of organic fertilizer to increase yield but they do not apply any kind of chemical fertilizer. It is because the principle use of uassava is household consumption and its commercial use is absent in Jhinaigati Upazila.

On the other hand, cassava farmers were found to use chemical fertilizers to get better production in Sreebardi Upazila. Average use of Urea, TSP, MoP and DAP were $47.69 \mathrm{~kg}, 28.46 \mathrm{~kg}, 17.94 \mathrm{~kg}$ and $16.99 \mathrm{~kg}$ per hectare respectively. While, average price of Urea, TSP, MoP, and DAP was BDT21.00, BDT 22.00, BDT 16.00 and BDT 30.00 respectively. Average cost per hectare was calculated as BDT1,001.58, BDT626.20, BDT286.99 and BDT 509.88 respectively. Total cost for chemical fertilizer was BDT 2,424.65 for cassava production among those cost incurred for Urea, TSP, MoP, DAP were $41.31 \%$, $25.83 \%, 11.84 \%$, and $21.09 \%$ respectively in Sreebardi Upazila.

Interest on operating capital was computed by taking all variable costs incurred for various operations such as human labor cost, tillage cost, seed cost, fertilizer cost, weeding cost. Interest on operating capital was computed at the rate of $12 \%$ for the study year. In this case, length of cassava production cycle was considered as 9 months. It was also found that many of the farmers did not borrow money from any formal or informal financial sources for financing their cassava farming. In this case, it was assumed that if a cassava farmer borrowed money from Microfinance Institutions or commercial or agricultural banks, he/she would have paid interest at the mentioned rate. Taking all these factors into consideration, interest on operating capital was estimated as BDT 1,592.98 in Jhinaigati Upazila and BDT 2,063.17 in Sreebardi Upazila for cassava production.

Table 2. Item wise cost of Cassava production

\begin{tabular}{|l|c|c|c|c|}
\hline \multirow{2}{*}{ Cost items } & \multicolumn{2}{|c|}{ BDT/hectare } & Percentage of total cost \\
\cline { 2 - 5 } & Jhinaigati & Sreebardi & Jhinaigati & Sreebardi \\
\hline Labor cost & $34,100.00$ & $35,800.00$ & 82.33 & 66.73 \\
\hline Power tiller cost & $3,078.29$ & $4,582.73$ & 7.43 & 8.54 \\
\hline Seed cost & $1,424.69$ & $4,091.38$ & 3.43 & 7.62 \\
\hline Organic Fertilizer cost & $1,221.26$ & $4,680.65$ & 2.94 & 8.72 \\
\hline Cost of chemical fertilizer & 0 & $2,424.65$ & 0 & 4.52 \\
\hline Interest on operating capital & $1,592.98$ & $2,063.17$ & 3.84 & 3.84 \\
\hline Total & $\mathbf{4 1 , 4 1 7 . 2 2}$ & $\mathbf{5 3 , 6 4 2 . 5 9}$ & $\mathbf{1 0 0}$ & $\mathbf{1 0 0}$ \\
\hline
\end{tabular}

Source: Authors'Own Calculation, 2012

Total variable cost of production: Considering all these cost items, calculated so far, total variable cost for Cassava was estimated as BDT 41,417.22in Jhinaigati Upazila whereas BDT 53,643.59 in Sreebardi Upazila (Table 2). Table 2 also shows that human labor cost is the major cost component in both the study areas which accounts for $82.33 \%$ and $66.33 \%$ of total variable cost in Jhinaigati and Sreebardi 
Upazila respectively. Another significant cost associated with cassava production was the cost of power tiller which accounts for $7.43 \%$ and $8.54 \%$ of total variable cost in Jhinaigati and Sreebardi Upazila respectively. Findings reveal that organic fertilizer cost is another significant cost in cassava production in Sreebardi Upazila which accounts for $8.72 \%$ of total variable cost. It is noteworthy to state that farmers in traditionally cassava grown areas in Jhinaigati Upazila had no cost involvement with the use of chemical fertilizers.

Yield of cassava: In general cassava is harvested after 9 to10 months of planting. With proper application of fertilizers the yield of cassava varies from $300-350$ mounds $(37.39 \mathrm{~kg})$ per hectare. Cassava crop is harvested by lifting the tubers from the soil. The soil around cassava stem is dug by a spade and the plant is then uprooted. The leaves of cassava were also used as vegetables. Moreover, dried stem (stick) of cassava is commonly used as firewood. The price of cassava leaves and dried stems were also taken into consideration for calculating total yield of cassava.

In Jhinaigati Upazila, average yield of cassava root was observed as 218.06 mounds per hectare. In addition, per hectare yield of cassava leaves was $185.33 \mathrm{~kg}$ and cassava stems (sticks) are 2,164.25 pieces. Average price of the cassava root was BDT 465.85 per mound, price of cassava leaves was BDT 5.63 per kg and price of sticks was BDT 0.31 per piece. On the other hand, in Sreebardi Upazila, average yield of cassava root was 273.01 mounds per hectare. However, no yield for cassava leaves was taken into account as it not used for consumption purpose in Sreebardi Upazila. Because, cassava is produced for commercial purpose in these areas, where priority is given mainly to root and stem production. Therefore, nobody looks for huge quantity of leaves produced from uncountable cassava plants. The yield of cassava sticks are 2,163.6 pieces. Average price of the cassava root was BDT 573.68 per mound and price of sticks was BDT 1.35 per piece.

Profitability of cassava production: Cost and return per unit was calculated to measure per unit profitability of the Cassava. Cost of production per unit was calculated through dividing total variable cost by total production. Gross margin per mound was calculated through dividing total gross margin over variable cost by total quantity.

Per hectare gross return was calculated by Gross return multiplying the total amount of product and byproduct with their respective market prices. In Jhinaigati Upazila, the average return for cassava was BDT 103,297.58 among which BDT 101,583.30 for root, BDT 1,043.41 for leaves as vegetables and BDT 670.92 for sticks as seed. In Sreebardi Upazila, cassava producers' average return was estimated as BDT 159,527.70 among which BDT 156,620.38 for root, and BDT 2,907.36 for sticks as seed.

Table 3. Returns and per hectare profitability from Cassava production

\begin{tabular}{|c|c|c|c|c|c|c|c|c|}
\hline \multirow[b]{2}{*}{ SI. No. } & \multirow[b]{2}{*}{ Item } & \multirow[b]{2}{*}{ Unit } & \multicolumn{3}{|c|}{ Jhinaigati } & \multicolumn{3}{|c|}{ Sreebardi } \\
\hline & & & $\begin{array}{c}\text { Root } \\
\text { (mound) }\end{array}$ & $\begin{array}{l}\text { Leaves } \\
(\mathrm{kg})\end{array}$ & $\begin{array}{l}\text { Sticks } \\
\text { (pieces) }\end{array}$ & $\begin{array}{c}\text { Root } \\
\text { (mound) }\end{array}$ & $\begin{array}{l}\text { Leaves } \\
(\mathrm{kg})\end{array}$ & $\begin{array}{l}\text { Sticks } \\
\text { (pieces) }\end{array}$ \\
\hline 1. & Quantity & & 218.06 & 185.33 & $2,164.25$ & 273.01 & 0 & $2,153.6$ \\
\hline 2. & Per unit price & BDT & 465.85 & 5.63 & 0.31 & 573.68 & 0 & 1.35 \\
\hline 3. & Total & BDT & $101,583.30$ & $1,043.41$ & 670.92 & $156,620.38$ & 0 & $2,907.36$ \\
\hline 4. & Gross return & BDT & \multicolumn{3}{|c|}{$103,297.58$} & \multicolumn{3}{|c|}{$159,527.70$} \\
\hline 5. & Total variable cost & BDT & \multicolumn{3}{|c|}{$41,417.22$} & \multicolumn{3}{|c|}{$53,642.59$} \\
\hline 6. & Gross margin(4-5) & BDT & \multicolumn{3}{|c|}{$61,880.36$} & \multicolumn{3}{|c|}{$105,885.10$} \\
\hline 7. & $\begin{array}{l}\text { Cost of production per } \\
\text { mound }(5 \div 1)\end{array}$ & BDT & \multicolumn{3}{|c|}{189.93} & \multicolumn{3}{|c|}{196.48} \\
\hline 8. & $\begin{array}{l}\text { Gross margin per mound } \\
(6 \div 1)\end{array}$ & BDT & \multicolumn{3}{|c|}{283.78} & \multicolumn{3}{|c|}{387.84} \\
\hline 9. & 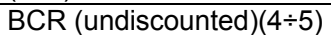 & & \multicolumn{3}{|c|}{2.49} & \multicolumn{3}{|c|}{2.99} \\
\hline
\end{tabular}

Note: 1 mound $=37.39 \mathrm{~kg}$

Source: Authors' Own Calculation, 2012

Gross margin is the difference between the gross return and total variable costs. Average gross margin for cassava was estimated as BDT 61,880.36 in Jhinaigati Upazila whereas BDT 105,885.10 in Sreebardi Upazila. 
Cost and return per unit of farmers: In Jhinaigati Upazila, average per unit cost for cassava production was estimated as BDT 189.93 whereas in Sreebardi Upazila BDT 196.48. Gross margin per mound cassava production was estimated as BDT 283.78 in Jhinaigati Upazila whereas BDT 387.84 in Sreebardi Upazila. It implies that use of modern production techniques i.e., farming inputs increased the cost of production and thereby increased the gross margin as well.

Benefit cost catio (BCR): Average return to each Bangladesh Taka spent in production is a vital criterion for measuring the profitability of growing any enterprise. Benefit cost ratio was calculated by dividing the total return by the total costs. It is a relative measure used to compare the benefit per unit of cost. Benefit cost ratio (BCR) was 2.49 for farmers in traditionally cassava grown Jhinaigati Upazila and 2.99 for commercially produced cassava farms. It clearly indicates that cassava cultivation was profitable for both the study areas. This high Benefit Cost Ratios, therefore, support a potential replication of cassava cultivation in other areas of Bangladesh.

Analysis of technical and economic efficiency: Table 4 represents estimates for the production functions parameters of equation (1) which reveal that all the estimated coefficients of the variables of the production function were positive except that of age of the farmers and quantity of seed/seedling and chemical fertilizers.

Table 4. Estimates of stochastic frontier models (Production function estimates)

\begin{tabular}{|c|c|c|c|}
\hline Variable & Parameters & Coefficients & t-ratio \\
\hline Constant & $\beta_{0}$ & 6.3292 & $7.787^{*}$ \\
\hline Age of farmers & $\beta_{1}$ & -0.8606 & 0.7843 \\
\hline Farm size & $\beta_{2}$ & 0.7944 & $7.787^{*}$ \\
\hline Labor days & $\beta_{3}$ & 0.4320 & $2.8622^{*}$ \\
\hline Quantity of seed/Seedling & $\beta_{4}$ & -0.5767 & 0.828 \\
\hline Quantity of chemical fertilizers & $\beta_{5}$ & 0.0001 & 0.1041 \\
\hline Quantity of organic fertilizers & $\beta_{6}$ & 0.8828 & $7.4014^{*}$ \\
\hline Variance parameter & - & - & - \\
\hline Sigma-square & $\sigma^{2}$ & 1.2735 & $9.851^{*}$ \\
\hline Gamma & $\mathrm{Y}$ & 0.9144 & $13.297^{*}$ \\
\hline
\end{tabular}

${ }^{*}$ Estimates are significant at $5 \%$ level of significance.

Source: Results of Authors' estimation, 2012

The positive coefficients of farm size, labor days and organic fertilizers imply that as each of these variables is increased, cassava output increased. While the negative coefficient of age of the farmers shows that as the farmers become aged, cassava output decreases. This finding is in conformity with the mean age of about 40.08 years recorded in the study area which implies that the farmers are relatively old. Similarly, the negative coefficient of quantity of seed/seedling implies that as number of seed/seedling planted in a particular area increased, cassava output decreases. Therefore, they had been with no vigor to accomplish the hard work associated with cassava production. On the other hand, if comparatively more quantity of seed or seedlings is planted in a particular cultivated area, less nutrient matter will be available for each seedling/cassava plant. Consequently, output will be decreased. Farm size and labor are significantly different from zero at $5 \%$ level of significance.

The technical efficiency analysis of cassava production reveals that technical inefficiency effects presence in cassava production in the study areas. It is confirmed by the gamma value of 0.9144 that was significant at $5 \%$ level (Table 4). The gamma ( $\mathrm{Y}$ ) value of 0.9144 implies that about $91 \%$ variation in the output of cassava farmers was due to differences in their technical efficiencies.

Table 5 represents the estimates for the stochastic frontier cost functions parameters of equation (2). The results revealed that all the independent variables conform to the prior expectations. It is because all the estimated coefficients, e.g., cost of labor, cost of power tiller, cost of seedlings, cost of organic fertilizer, and interest on operating capital gave positive coefficients. This implies that as these factors increased, total production cost increased under the condition that all other situations will remain unchanged. The result of t-ratio test shows that all the variables are statistically different from zero at $5 \%$ level of significance. Hence, these variables are important determinants of cassava production in the study area. 
The economic efficiency analysis of cassava farmers revealed the presence of cost inefficiency effects in cassava production as confirmed by the significance gamma value of 0.947 at $5 \%$ level (Table 5 ). This implies that about $95 \%$ variation in the total production cost is due to differences in their cost efficiencies.

Table 5. Estimates of Stochastic Frontier Models (Cost Function Estimates)

\begin{tabular}{|l|l|l|l|}
\hline Variable & Parameters & Coefficients & t-ratio \\
\hline Constant & $\mathrm{a}_{0}$ & 3.9215 & $10.626^{*}$ \\
\hline Cost of labor & $\mathrm{a}_{1}$ & 0.1447 & $6.0841^{*}$ \\
\hline Cost of power tiller & $\mathrm{a}_{2}$ & 1.5818 & $2.9491^{*}$ \\
\hline Cost of planting materials (stem cuttings) & $\mathrm{a}_{3}$ & 0.2607 & $5.104^{*}$ \\
\hline Cost of organic fertilizer & $\mathrm{a}_{4}$ & 0.1672 & $3.6223^{*}$ \\
\hline Interest on operating capital & $\mathrm{a}_{5}$ & 0.1256 & $3.6341^{*}$ \\
\hline Variance parameter & & & \\
\hline Sigma -square & $\sigma^{2}$ & 0.8162 & $6.028^{*}$ \\
\hline Gamma & $\mathrm{V}$ & 0.947 & $4.323^{*}$ \\
\hline
\end{tabular}

*Estimates are significant at $5 \%$ level of significance.

Source: Results of Authors' estimation, 2012

\section{Conclusion}

As a food cassava is new to Bangladeshi people and not commonly cultivated all over the country. From the foregoing analysis of various costs, yields and returns per hectare of cassava cultivation, it can be summarized that cassava is a profitable crop. Although cassava production is profitable, technical inefficiency effects presence in its production in the study areas. The economic efficiency analysis suggest that in order to ensure the profitability and thereby popularizing of such rare crop in Bangladesh some policy interventions for reducing the cost of production are necessary. Hence, the use of modern inputs such as high yielding variety of seed, optimum use of fertilizer and use of modern technology are recommended for reducing the cost of production and increase the profitability of cassava. In a nutshell, though the technical inefficiency exists in the cassava production, it is profitable and, therefore, be replicated in other areas of Bangladesh.

\section{References}

Ajibefun, I.A., Battese G. E. and Kada. R. 2002. Technical Efficiency. Technological Change and Productivity of Hired and Family Labour in the Japanese Rice Industry.

Arena, P. 2005. Mobilizing Science and Technology for Development: The Case of the Cassava Biotechnology Network (CBN). In: $\left(9^{\text {th }}\right.$ ICABR International Conference on Agricultural Biotechnology: Ten years later, 6 to 10 July 2005, Ravello, Italy.

Brave-ureta, B. and Pinheiro, A.E. 1997, Technical, Economic, and Allocative Efficiency in Peasant Farming: Evidence from the Dominican Republic, The Developing Economies, XXXV-1 (March 1997): 48-67

Coelli, T.J. 1996. A Guide to FRONTIER version 4.1c: A Computer programme for Stochastic Frontier production and Cost Function Estimation": Working paper 96/07, Centre for Efficiency and Productivity Analysis, Dept. of Econometrics, University of New England, Armidale, Australia

FAOSTATE. 2001..Available at http://www.apps.fao.org//giews/ accessed on 7/8/2012.

Shams-Ud-Din, Md. and Talukder, R.K. 2002. Processing of Cassava for Improving Livelihood of Rural Communities, Department of Food Technology \& Rural Industries, Bangladesh Agricultural University, Mymensingh, Published by: REFPI Project of the DFID of the UK.

Yang, W.Y. 1965. Methods of farm management investigation for improving fro productivity, Food andAgriculture Organization of the United Nations, Rome, Italy. 